\title{
Predicting Potential Zones of Hydrocarbon through Seismic Stratigraphy within the Western Barents Sea, Norway
}

\author{
Muhammad Rizwan Mughal ${ }^{1,2, a}$, Muhammad Farooq Iqbal ${ }^{1, b^{*}}$, \\ Irfan Mahmood ${ }^{1, c}$, Furqan Mahmud Butt ${ }^{1,2, d}$ and Kalim Ullah ${ }^{1, e}$ \\ ${ }^{1}$ Department of Meteorology, COMSATS Institute of Information Technology, Islamabad, Pakistan \\ ${ }^{2}$ Department of Earth Sciences, Quaid-i-Azam University, Islamabad, Pakistan \\ arizwan.mughal@comsats.edu.pk, *bfarooqbuzdar@gmail.com, ${ }^{c}$ irfan.mahmood@comsats.edu.pk, \\ dfurqan.mahmud@comsats.edu.pk, 'kalim_ullah@comsats.edu.pk
}

Keywords: Barents Sea, seismic stratigraphy, reservoir zones, stratigraphic trap, common risk segment.

Abstract. Stratigraphic play based exploration approach facilitates the development of reservoir prediction models and prospect generation. The present study is carried out along the southern margin of the Loppa High within Hammerfest Basin, Barents Sea, Norway in order to identify the reservoir quality sand in Early Cretaceous age formations along the slope of the high. In this study 2D seismic lines; in which 8 lines are dip and 1 line is strike, and well logs data are interpreted. Outcome is a low-risk exploration technique that is capable of correctly predicting reservoir zones. The stratigraphic trap is identified in the Knurr and Kolje Formations of Adventdalen group, which act as source and seal rock for reservoir respectively. Three stratigraphic surfaces including base of Knurr Formation (sequence boundary), top of Knurr Formation, and Kolje Formation (maximum flooding surface) make a perfect trap for hydrocarbon accumulation. By utilizing the common risk segment analyses, it was identified that the maximum chances of hydrocarbon accumulation are in reservoir zone A and B which lies in up-dip direction.

\section{Introduction}

The understanding of source rock composition, thermal maturity and reservoir rocks are key components for the prediction of potential hydrocarbon zones [1-4]. In addition, stratigraphic frameworks and basin modeling (numerical estimations) have been widely applied with respect to geological and paleoclimatic characteristics for evaluating key petroleum elements in the literature [5-9].

Barents Sea geology comprises of complicated sub- basins and platforms. Barents Sea underwents intercontinental sedimentation from 240 million years to 60 million years, which is almost the start of Cenozoic Era. This time period is also followed by development of marine environments between the borders of Arctic and Atlantic Oceans [10]. The structures, bedrock and the glacial erosion from the Cenozoic Era strongly influenced the topography of present Barents Sea [11]. During the last thirty years the regional seismic studies along with wells provide the information about the structural complexities and stratigraphic components of the area [12]. Average to fairly high exploration success rate has been recorded in the Barents Sea because drilled wildcat wells have indicated that just over a third of the hydrocarbons are capable of reaching the surface [13]. The main reservoirs like Hammerfest and Tromso basins were exploited in the Norwegian sector because the mentioned reservoirs were believed to contain very large amounts of hydrocarbons and source rocks similar to those that were proven prospective in the North Sea exploration [14]. In the current study, seismic stratigraphic interpretation is done to identify different horizons of hydrocarbon potential and to study the lithological behaviors to delineate the zones of reservoir perspective along with the sequence and geological studies. The location map of the study area is displayed in Fig. 1. 


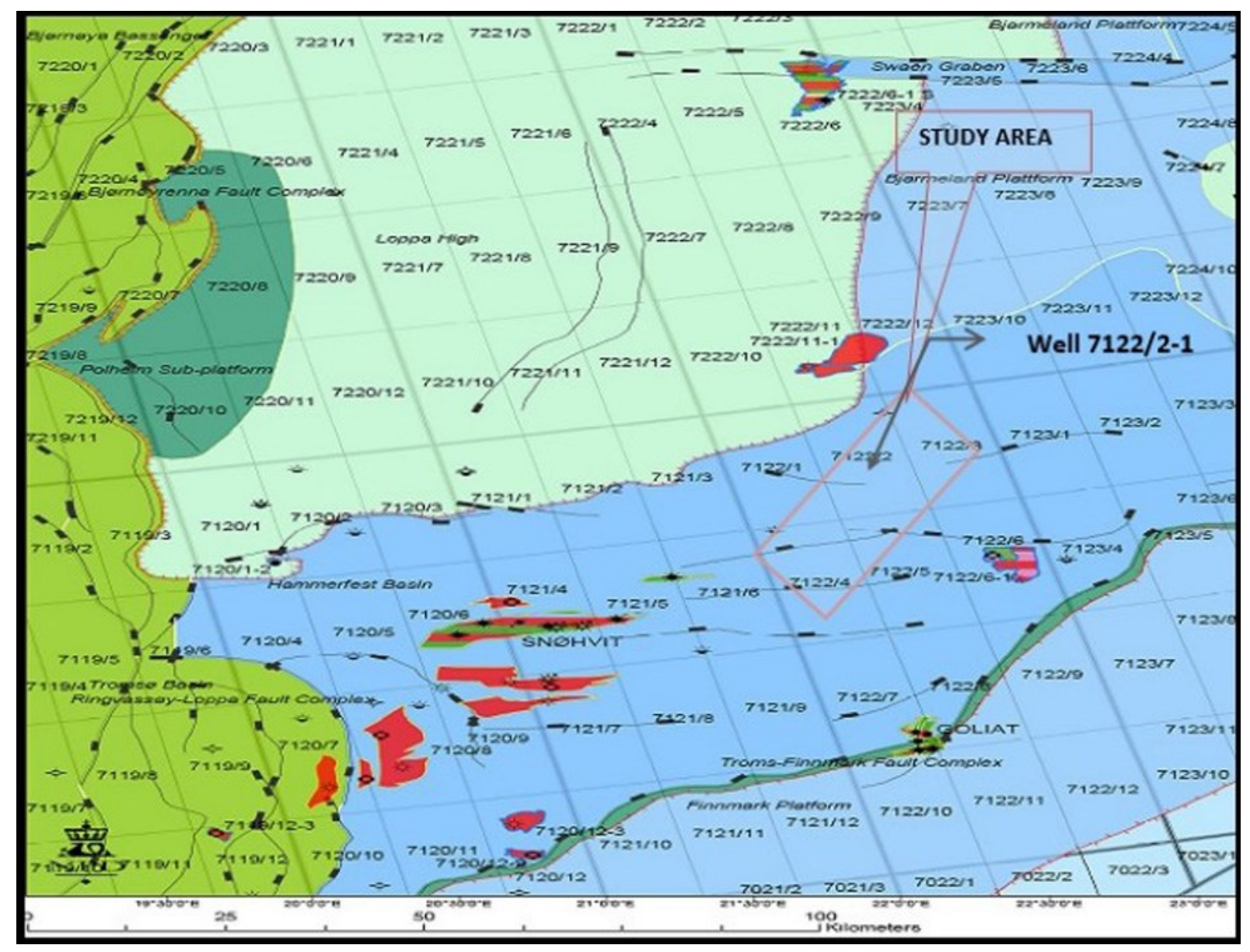

Figure 1. Location map of the study area.

\section{Stratigraphy of the area}

The study area covers five major stratigraphic groups including Adventdalen group. The group further includes the stratigraphic Formations of our interest namely Kolmule, Kolje, Knurr and Hekkingen Formation (Fig. 2). Development of this group started between Middle Jurassic to Early Cretaceous. It is widely exposed in the eastern Spitsbergen and also along the margins of the Central Basin. Significant organic contents like thin condensed carbonate beds, dark marine mudstones, deltaic and shelf sandstones are dominantly present in this group [11].

Thickness of this group in the Svalbard area is close to 750-1600 $\mathrm{m}$ and the known thickness on the Barents Sea Shelf is almost 1000-1750 m and the lithology comprises of shales, siltstones, and sandstones of Late Jurassic to Early Cretaceous age in Svalbard and throughout the Barents Sea Shelf [15]. It is widely exposed along the margins of the Central Tertiary Basin on Spitsbergen, as well as in eastern Spitsbergen (Sabine Land) and on Kong Karls Land. It continues across the Barents Sea Shelf to the Bjarmeland Platform, around the Loppa High and into the Hammerfest and Nordkapp basins. It was eroded down to varying levels during the Late Cretaceous uplift. On the southern Barents Sea Shelf, this hiatus comprises only the Cenomanian and part of the Turonian, while the entire Late Cretaceous is lacking on Svalbard [16].

Dark marine mudstones dominate the Adventdalen group. Deltaic and shelf sandstones as well as thin, condensed carbonate beds are also present in the group. The black shales of the Upper Triassic are excellent source rocks for petroleum in the Barents Shelf's western part. It has almost $20 \%$ of the organic content with the marine dominated kerogens [17]. Regional history shows that subsequent burial of the sediments has generated significant hydrocarbons and this has happened in the basinal areas' western part and perhaps locally in the deeper parts of the Nordkapp Basin [12, $16]$. 


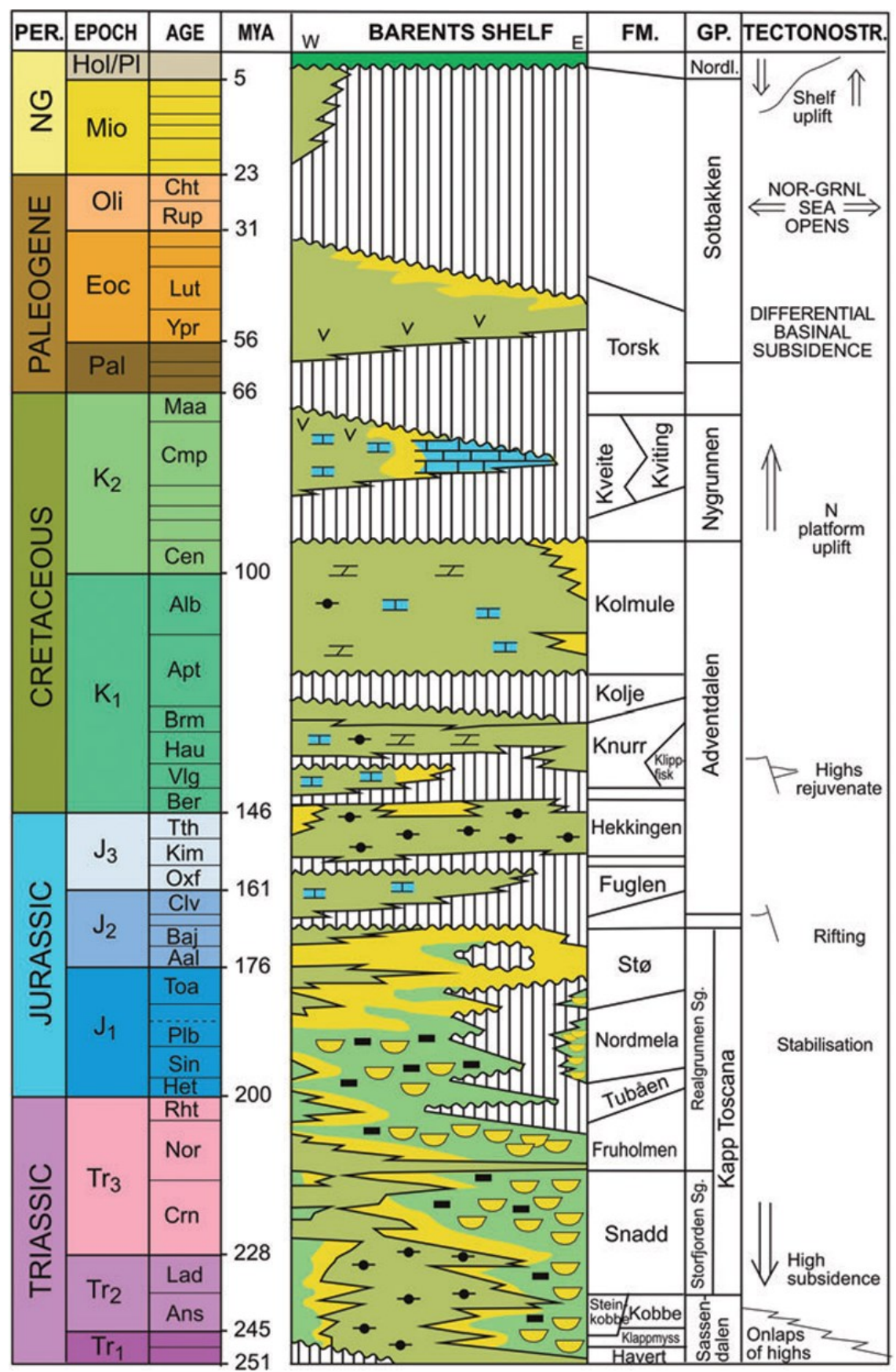

Figure 2. The Mesozoic and Cenozoic development of the south-western Barents Sea, modified from Worsley, (2008) [12], with the geological time scale, after Gradstein et al., (2004) [18].

\section{Data and Methodology}

Data set comprises of formation logs of well 7122/2-1 and 2D seismic lines in which 8 lines are dip and 1 is strike line, given in SEG-Y format (Fig. 3). PETREL 2010 software is used for interpretation. Seismic horizons are marked on the basis of reflection and well data using European format seismic logs having reverse polarity and positive reflection coefficients. Hydrocarbon potential zones are predicted through correlation of regional and previous stratigraphy. Stratigraphic surfaces which act as source and seal rocks are interpreted. The hydrocarbon trap zones are marked through common risk segment. 


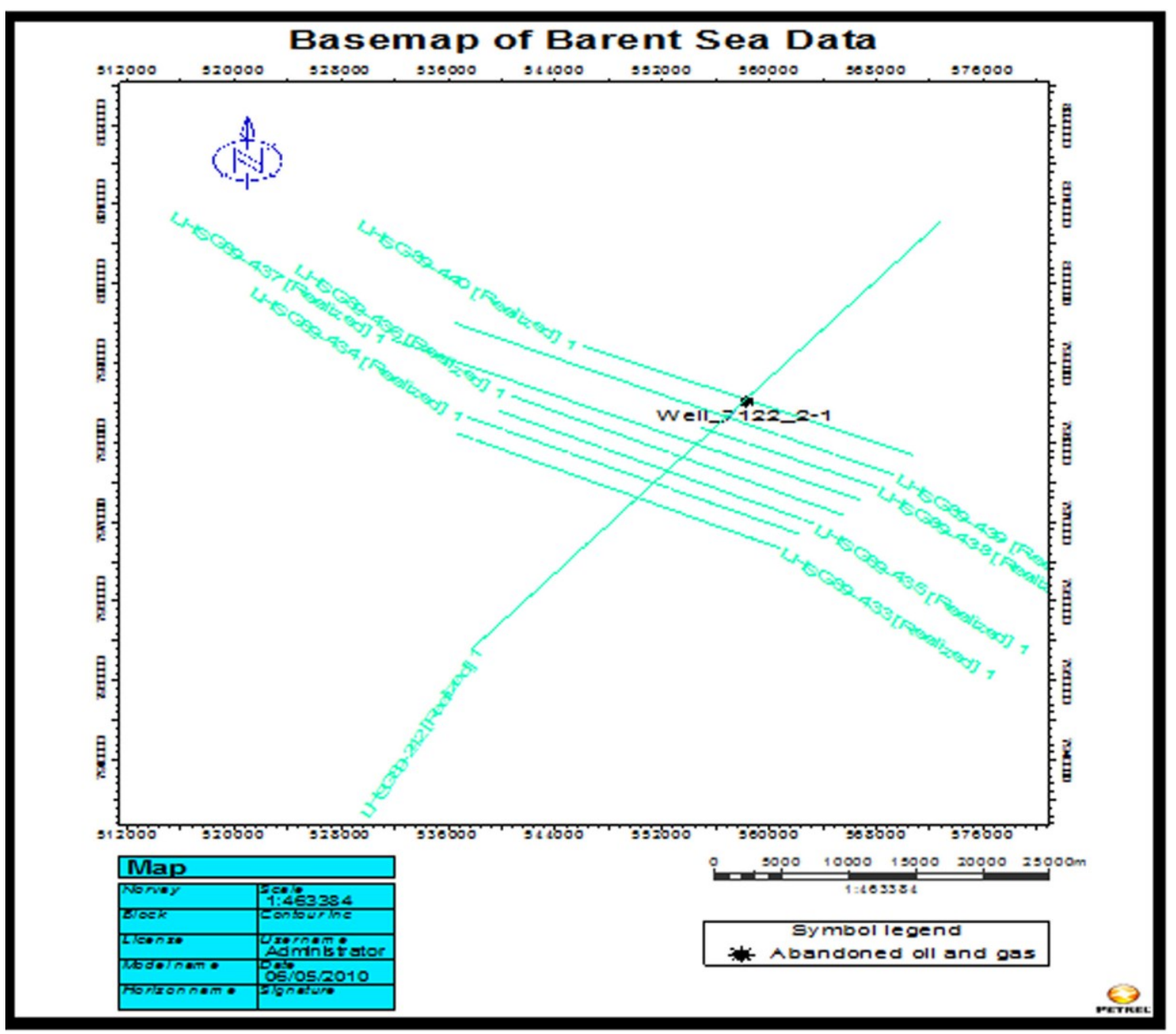

Figure 3. Base map of the study area showing location of the well and seismic lines.

\section{Results and Discussion}

Fig. 4 displays the interpreted seismic section of strike line LHSG-89-242. Three different surfaces including Maximum Flooding Surface (MFS), top and base of Knurr Formation are marked on the bases of their reflection and well data and also tied them with the entire cross cutting lines. The MFS is the Kolje Formation, Knurr top and base is the Transgressive System Tract (TST) and sequence boundary (SB) respectively. An Early Cretaceous turbidite sand lobe of Knurr Formation has been interpreted as forced regressive wedge lying away from the Loppa High slope. The high resolution parallel lines show shaling out of lobe in both the proximal and distal direction.

A channel shaped area is seen within the Knurr Formation, in the up-dip direction the top of Knurr Formation merge into the SB and the overlaying Kolje Formation, making a perfect trap for hydrocarbon accumulation (Fig. 5). From Figure 5, our reservoir which is Knurr Formation lies between the TST and MFS.

The isopach map displays lines of equal thickness in all 3 surfaces perpendicular to their boundaries. Whereas, the isochor map shows lines of equal thickness parallel to their boundaries making a play fare for hydrocarbon trap in the area (Fig. 6). The calculated average velocity from seismic data is $3600 \mathrm{~m} / \mathrm{sec}$ in the reservoir zone for both isopach and isochor maps. 


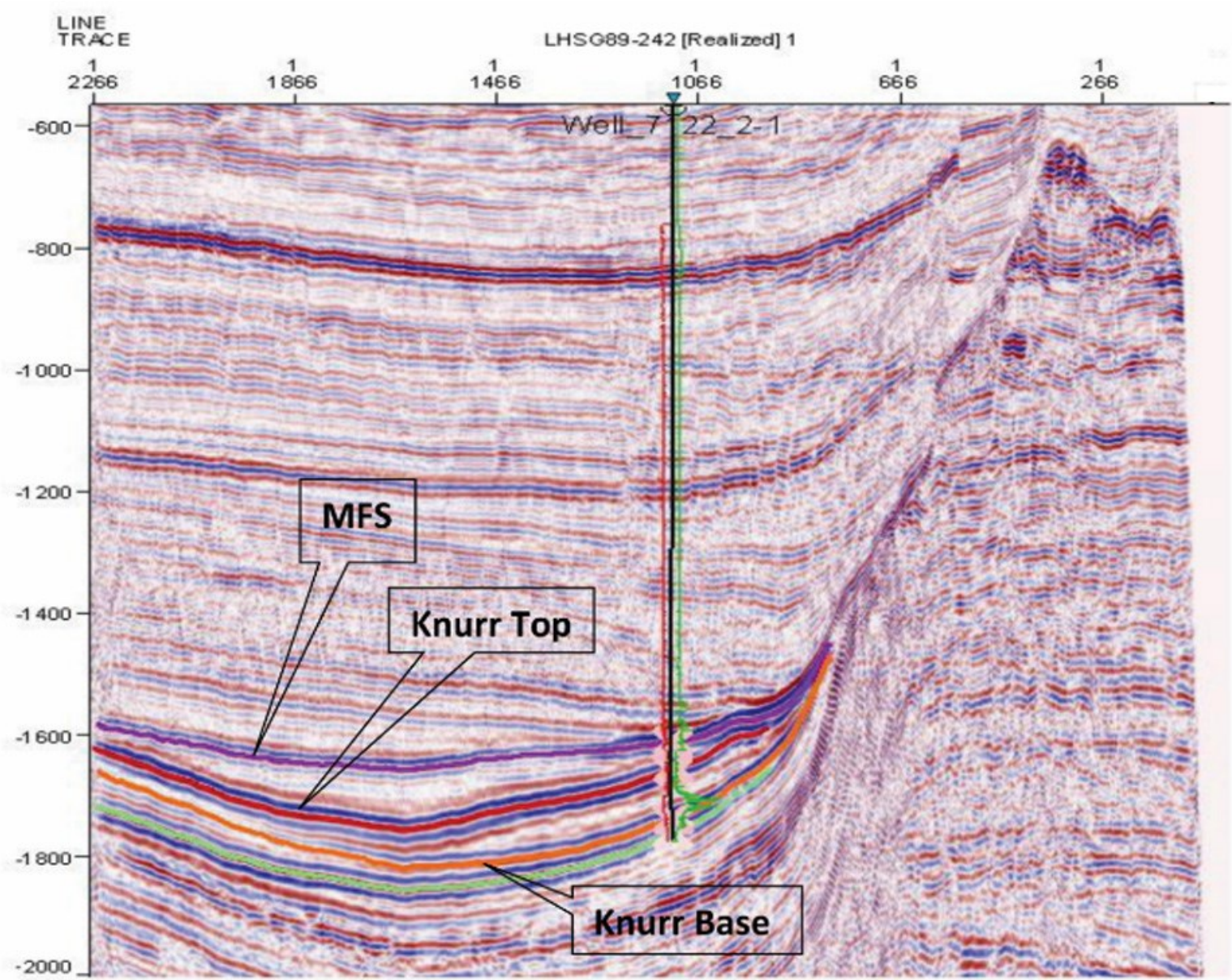

Figure 4. Seismic section of strike line LHSG89-242 with well showing MFS, top and base of knurr Formation.

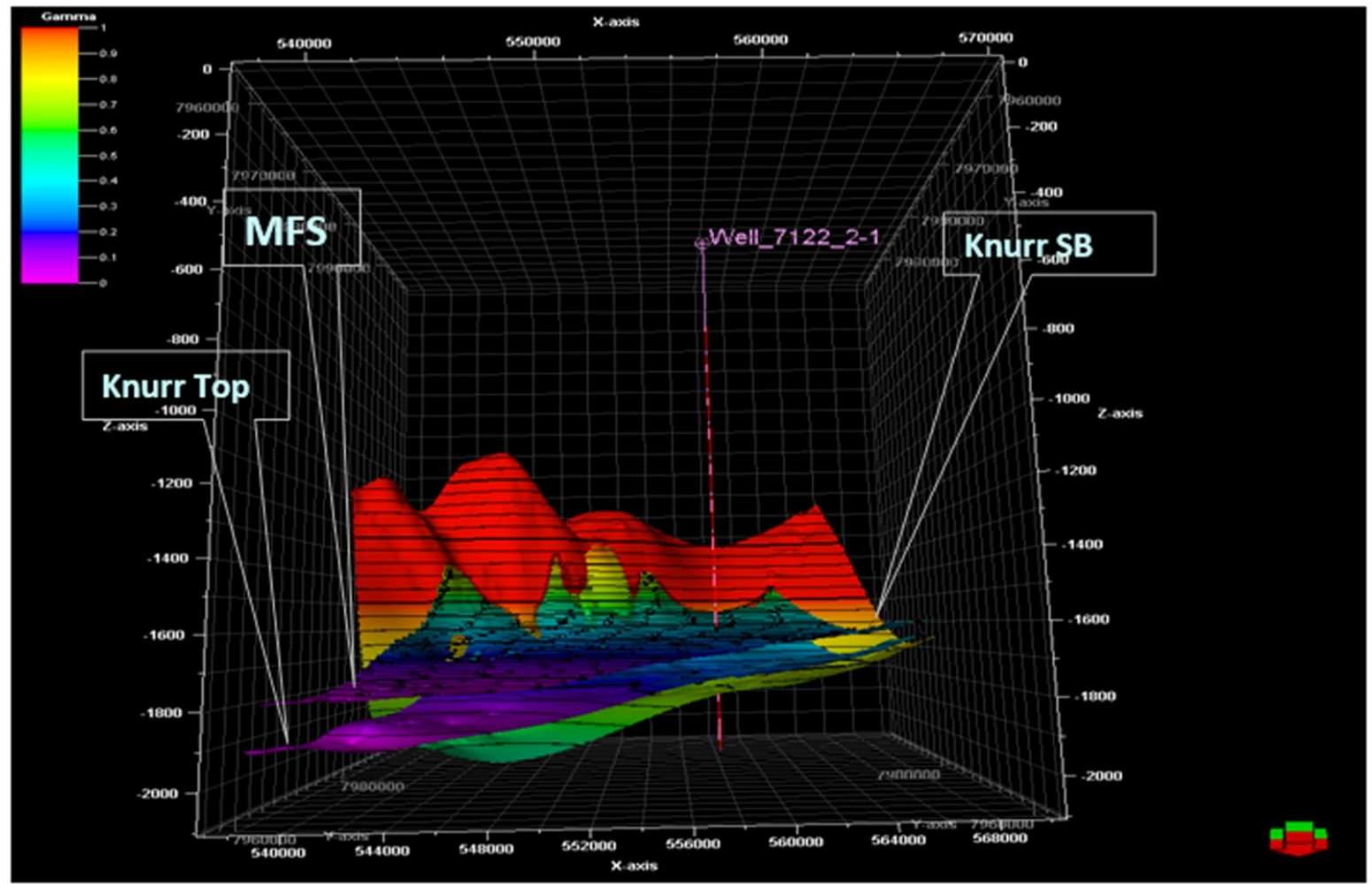

Figure 5. Display of Knurr SB, Knurr top and MFS with well. 


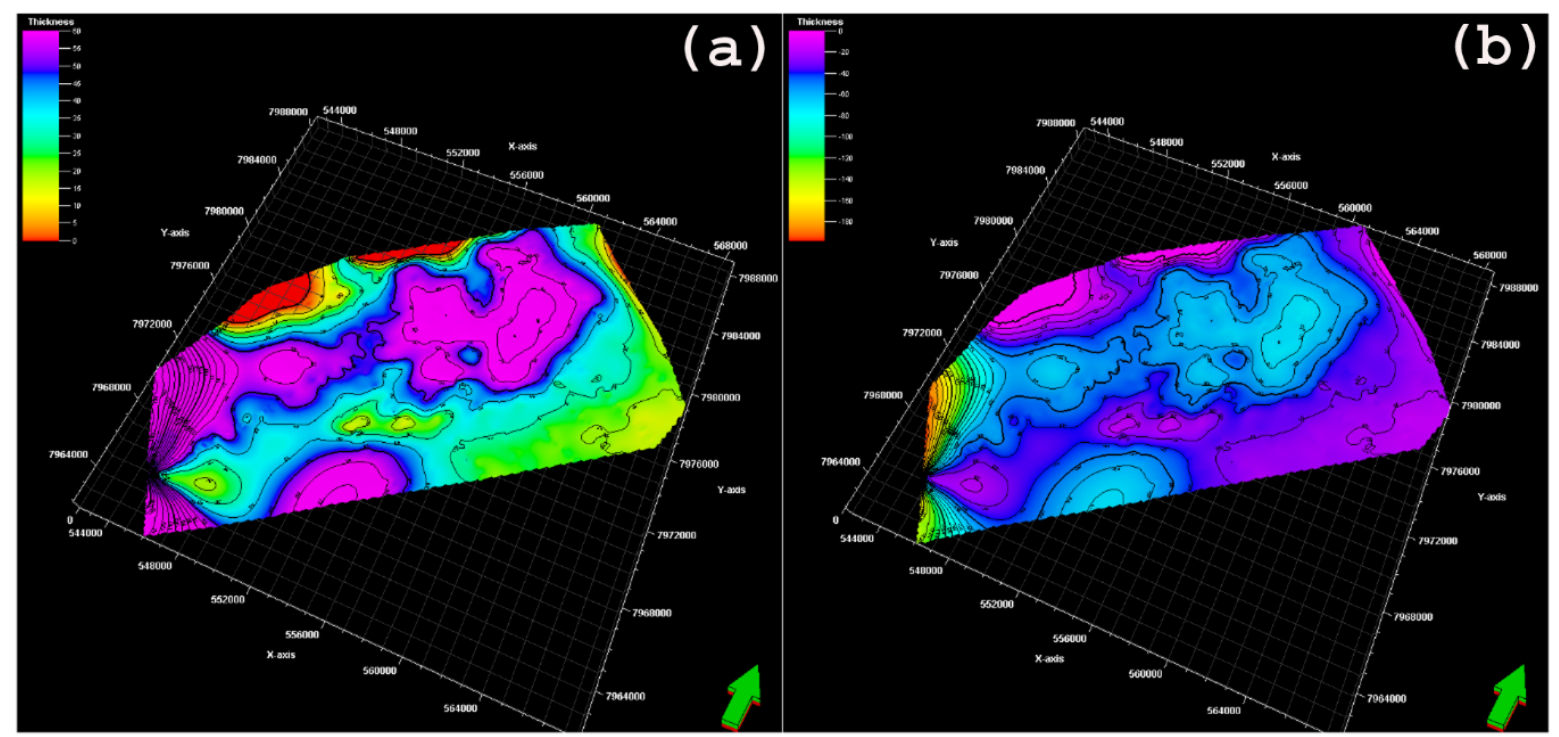

Figure 6. Thickness variations of surfaces shown in (a) Isopach and (b) Isochor map.

Figure 7 shows the base of Knurr formation (SB) spread over the area of Loppa High. The contour shows a gentle and smooth variation toward the center of the basin. The sediments are filling the basin from all three sides making a curve shaped depositional front consequently, making a reservoir trap.

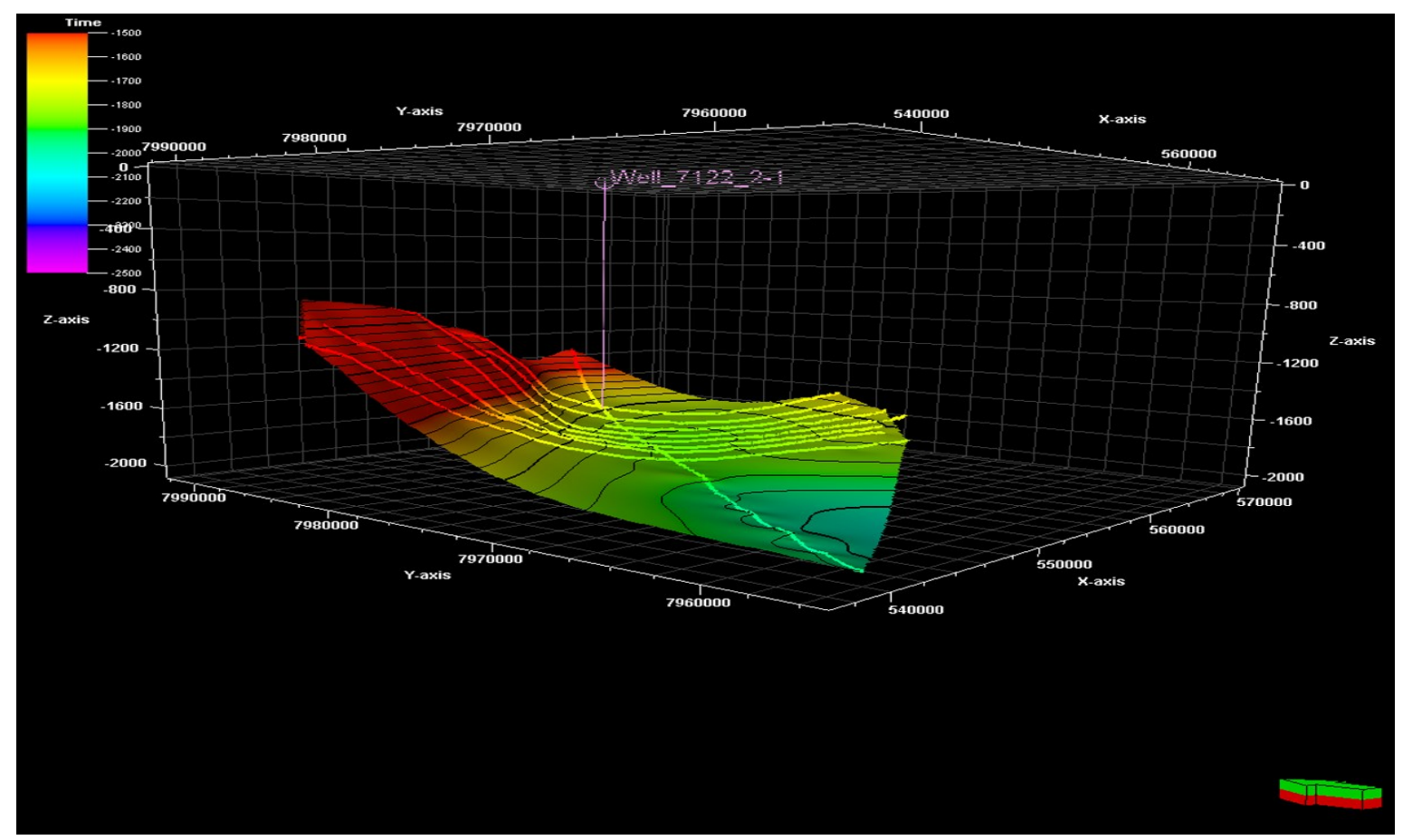

Figure 7. Base of Knurr Formation (SB) with seismic lines and well.

\section{Reservoir allocation}

Figure 8 displays SB with Knurr Formation top grid. An Early Cretaceous uplift on Loppa High accompanied by a relative sea-level fall and subaerial exposure caused deeply eroded incised valleys. These valleys provided feeder systems for the Knurr sandstone turbidite lobes deposited as slope-to-basin floor fans in the Hammerfest Basin. 


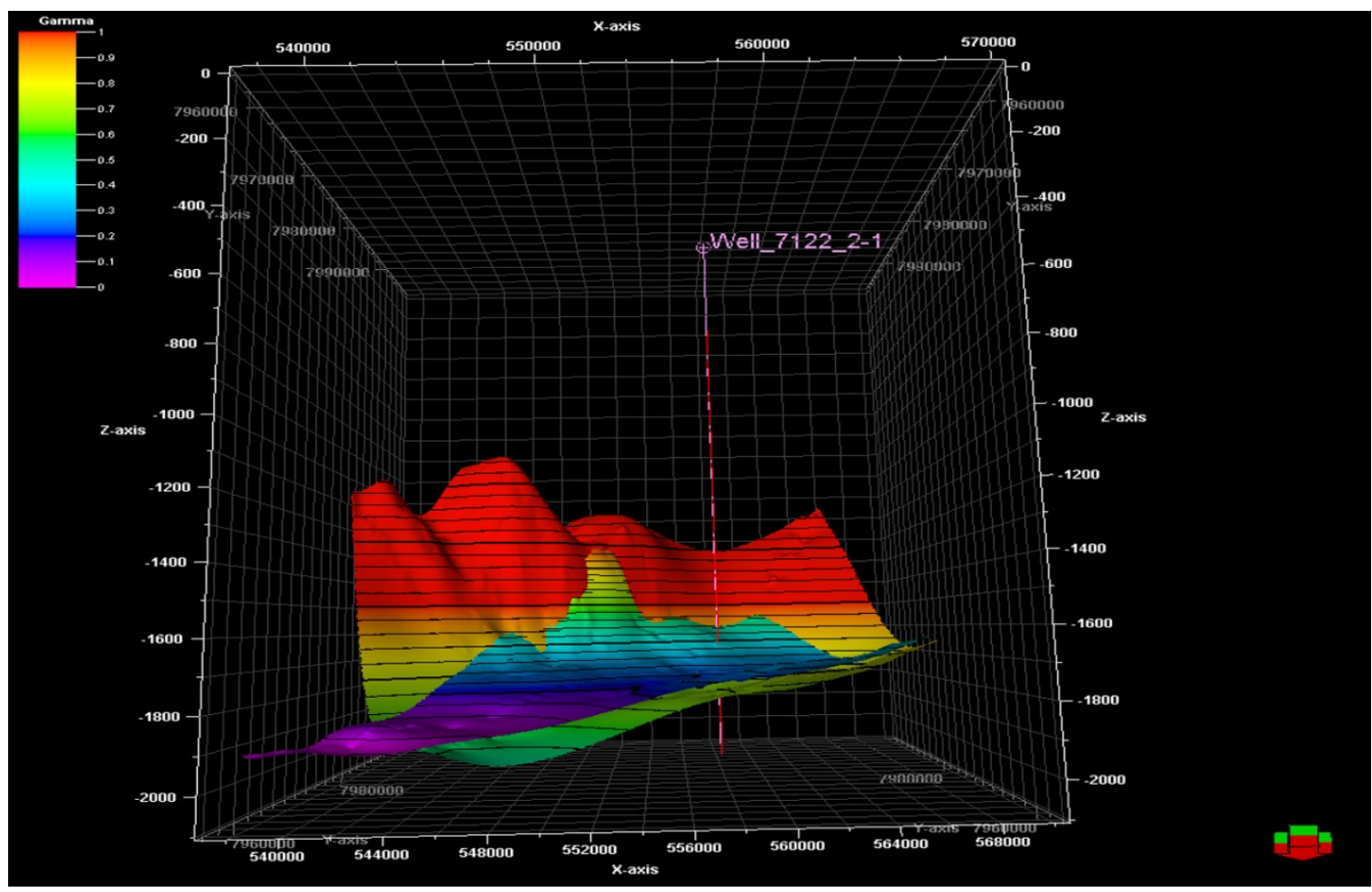

Figure 8. Base of Knurr Formation (SB) with Knurr Formation top grid with well.

A part of the Knurr Formation subsidies as it moves toward the distal side making a channel shaped structure, which is further filled by Kolje Formation shale. The contour values show gentle spreading of seal rock (Kolje Formation) laying over the source rock, which marked as a good seal for Knurr reservoir (Fig. 9).

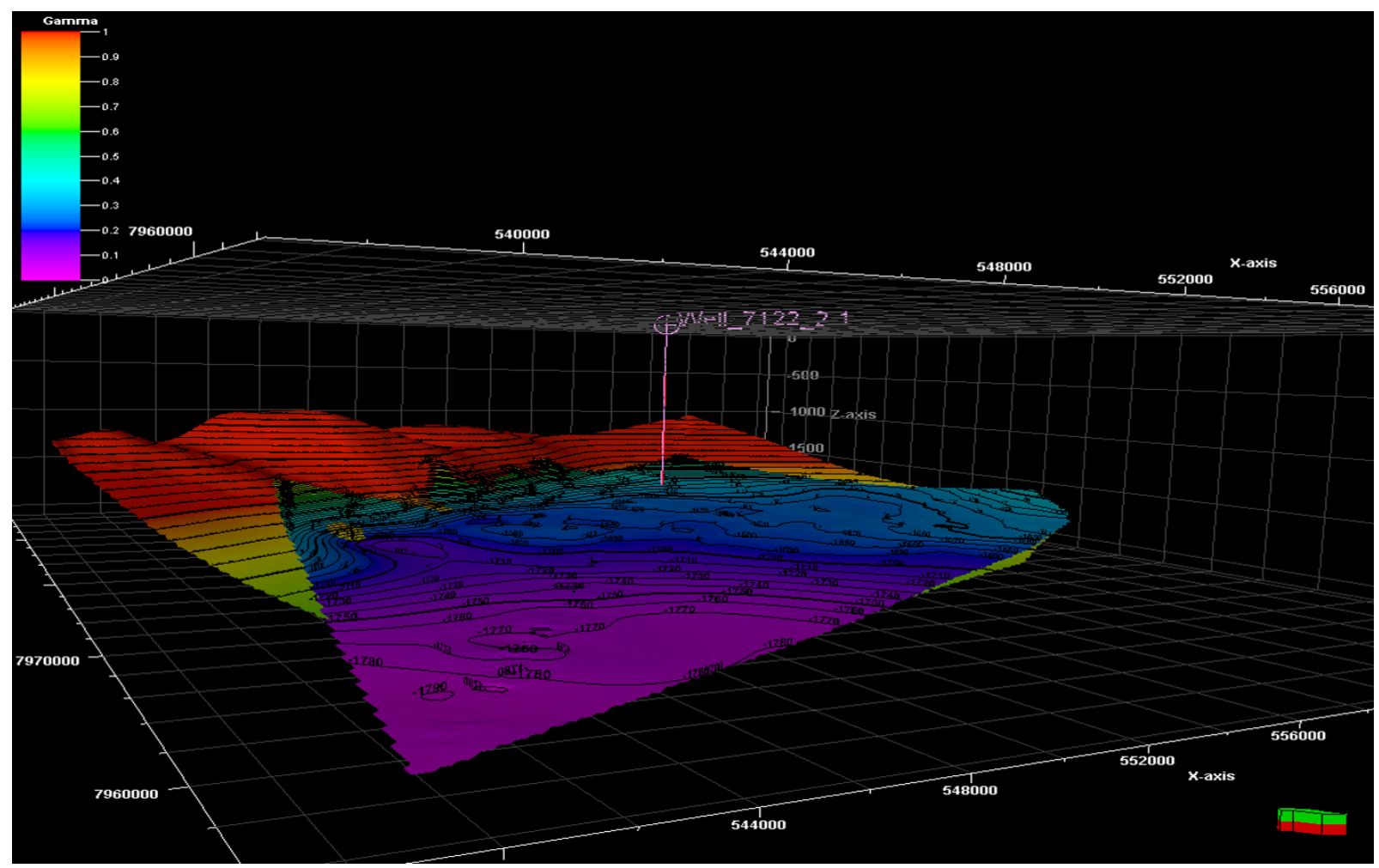

Figure 9. Seal rock laying over the source rock. 


\section{Common Risk Segment}

Figure 10 displays reservoir zones for hydrocarbon accumulation. The contour values are closing up at lower middle portion of Knurr Formation which shows the Knurr sand slips toward the basin side creating space for the shales of Kolje Formation to settle here, displaying this portion of Knurr Formation is plugged with shale of Kolje Formation creating a shale plunge, which will trap the hydrocarbon. The hydrocarbon moves in up-dip direction consequently, maximum chances of hydrocarbon growth will be in zone A and B. The Knurr sand is almost blocked from all sides by Kolje shale consequently, making a zone of hydrocarbon accumulation.

The occurrence of hydrocarbon is less in zone $\mathrm{C}$ because its west ward extension is unknown and its north-west side is blocked by shale plug and from south-ward side it is in basin ward direction. The remaining portion of reservoir has very low percentage of hydrocarbon accumulation due to adjacent shale plug region. In south the percentage of hydrocarbon is high because it will block by the shale plug in up-dip direction.

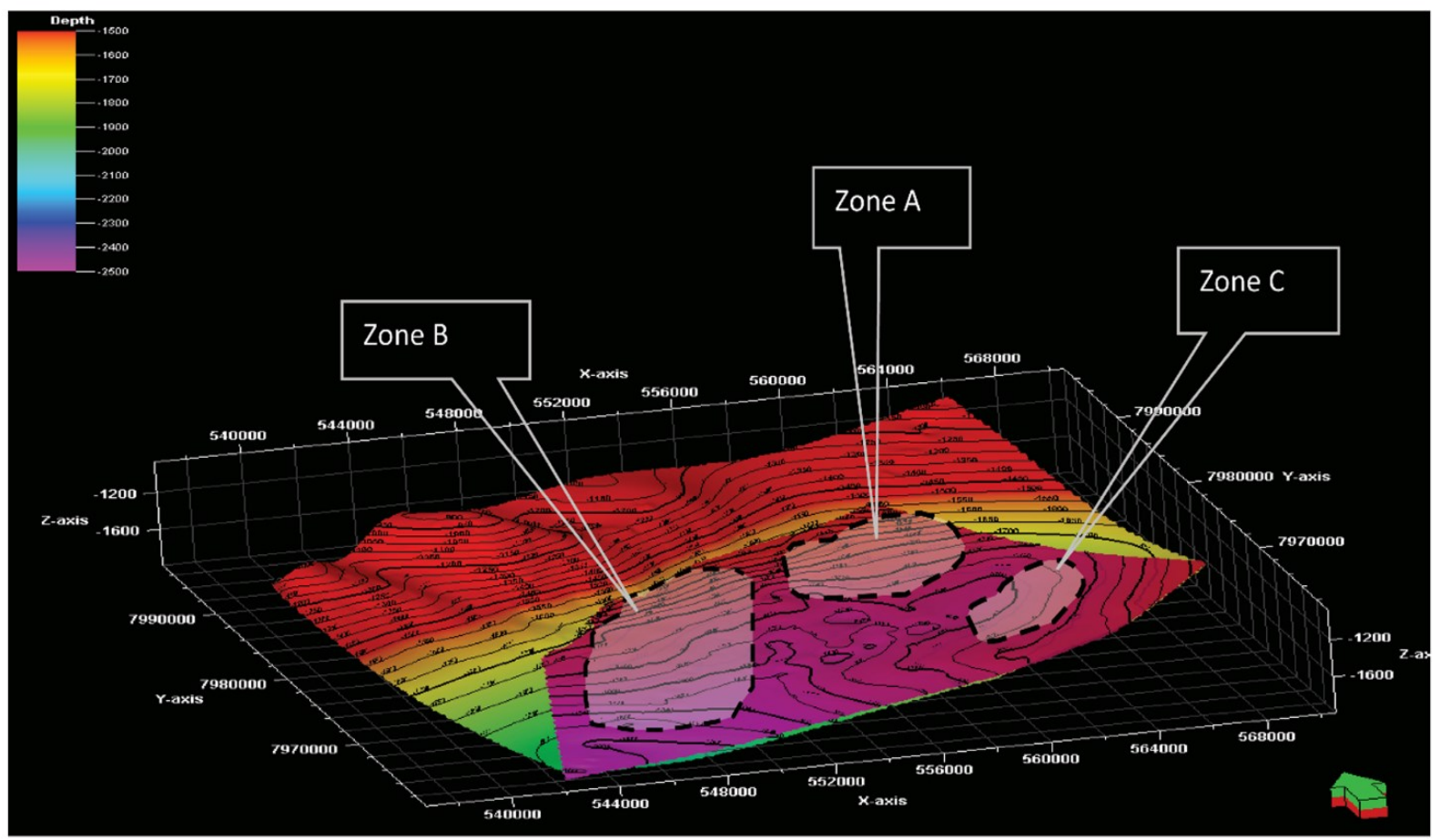

Figure 10. Reservoir zones (A, B and C) for hydrocarbon accumulation.

\section{Conclusion}

Much development has been done in recent years to reduce risk of exploration targets. The purpose is to identify the best reservoir zone of hydrocarbon potential in terms of seismic stratigraphy. The stratigraphic trap is present in the Knurr and Kolje Formations of Adventdalen group. The trap is justified through common risk segment by demarcation of hydrocarbon zones. In Hammerfest Basin, mostly Jurassic age rock gives good production which mostly lies in between High System Tracts and Transgressive System Tracts. But the study of Cretaceous age rocks in our area showed a very good stratigraphic trap. Geological uncertainties can be de-risk through 3D seismic acquisition and integrated use of high-resolution sequence stratigraphy and attribute maps which led to the winning exploration strategy for targeting stratigraphic traps in the region.

\section{Acknowledgment}

The research project was done at Schlumberger, Islamabad-Pakistan. The authors would like to thank Schlumberger for giving permission and providing public domain data and software usage to conduct research in excellent environment for the current study. 


\section{References}

[1] B.P. Tissot, D.H. Welte, Petroleum formation and occurrences, Springer-Verlag, New York, 1978.

[2] K.E. Peters, Guidelines for evaluating petroleum source rock using programmed pyrolysis, The American Association of Petroleum Geologists Bulletin. 70 (1986) 318-329.

[3] A.S. Ratnayake, Y. Sampei, Characterization of organic matter and depositional environment of the Jurassic small sedimentary basins exposed in the northwest onshore area of Sri Lanka, Researches in Organic Geochemistry. 31 (2015) 15-28.

[4] A.S. Ratnayake, Y. Sampei, Preliminary prediction of the geothermal activities in the frontier Mannar Basin, Sri Lanka, Journal of Geological Society of Sri Lanka. 17 (2015) 19-29.

[5] B. Tissot et al., Paleoenvironment and petroleum potential of Middle Cretaceous black shales in Atlantic Basins, The American Association of Petroleum Geologists Bulletin. 64 (1980) 2051-2063.

[6] A.S. Pepper, P.J. Corvi, Simple kinetic models of petroleum formation. Part I: oil and gas generation from kerogen, Marine and Petroleum Geology. 12 (1995) 291-319.

[7] A.S. Pepper, T.A. Dodd, Simple kinetic models of petroleum formation. Part II: oil-gas cracking, Marine and Petroleum Geology. 12 (1995) 321-340.

[8] A.S. Ratnayake, Regionwide geodynamic analyses of the Cenozoic carbonate burial in Sri Lanka related to climate and atmospheric $\mathrm{CO}_{2}$, International Journal of Economic and Environmental Geology. 7 (2016) 1-9.

[9] A.S. Ratnayake, Y. Sampei, C.W. Kularathne, Stratigraphic responses to major depositional events from the Late Cretaceous to Miocene in the Mannar Basin, Sri Lanka, Journal of Geological Society of Sri Lanka. 16 (2014) 5-18.

[10] S.O. Johnsen et al., Outline of the geology of Svalbard, In 7th ESF IMPACT Workshop, 2001.

[11] J.I. Faleide et al., Late Cenozoic evolution of the western Barents Sea-Svalbard continental margin, Global and Planetary Change. 12 (1996) 53-74.

[12] D. Worsley, The post-Caledonian development of Svalbard and the western Barents Sea, Polar Research. 27 (2008) 298-317.

[13] N.P. Directorate (Ed.), The Petroleum Resources on the Norwegian Continental Shelf, Norwegian Petroleum Directorate, 1993.

[14] S. Westre, The Askeladden gas find-Troms I. In Petroleum Geology of the North European Margin, Springer Netherlands. (1984) 33-39.

[15] S.E. Johansen et al., Hydrocarbon potential in the Barents Sea region: play distribution and potential, Arctic Geology and Petroleum Potential, Norwegian Petroleum Society (NPF), Special Publication. 2 (1992) 273-320.

[16] W.K. Dallmann (Ed.), Lithostratigraphic lexicon of Svalbard: review and recommendations for nomenclature use, Upper Paleozoic to Quaternary bedrock, Norsk Polarinstitut. Tromso, 1999.

[17] C.R. Scotese, L.M. Gahagan, M.I. Ross, Phanerozoic plate tectonic reconstructions. Paleoceanographic mapping project, Institute for Geophysics, University of Texas, Technical Report. 90 (1987).

[18] F.N. Gradstein, J.G. Ogg, A.G. Smith (Eds.), A geologic time scale 2004, Cambridge University Press., Cambridge, 2004. 